\title{
ОСОБЛИВОСТІ ЮРИДИЧНОЇ ВІДПОВІДАЛЬНОСТІ ПРОФЕСІЙНОГО ПУБЛІЧНОГО СЛУЖБОВЦЯ В УКРАЇНІ
}

Любимов О. $K$.

у статmі робиться спроба комплексно окреслити юридичну сутність феномена службово-трудової відповідальності професійних публічних службовців в Україні на основі концепції трудоправової відповідальності. Автором аналізуються наукові підходи українських вчених до розуміння сутності юридичної відповідальності в трудовому праві України та виокремлюється підхід до розуміння цієі відповідальності, у межах якого можливо найбільш повно сформулювати юридичний конструкт «службово-трудової відповідальності професійних публічних службовців».

В якості такого підходу використовується консолідуючий (гармонійний) підхід до розуміння юридичної відповідальності в трудовому праві, який був сформульований в українській теорії трудового права. Значна увага приділяється дослідженню особливостей вияву дисциплінарноі та матеріальної відповідальності у межах службово-трудової відповідальності професійних публічних службовців. Визначено, що юридична відповідальність публічного службовця характеризується певними притаманними тільки їй особливостями, різновидами та розширеними підставами для їі настання. Застосування до публічного службовця певного виду юридичної відповідальності передбачає не тільки осуд поведінки публічного службовця шляхом застосування до нього публічного примусу, а й стимулює інших осіб до належної поведінки та належного виконання своїх посадових обов'язків, недопущення вчинення дій, які прямо заборонені чинним законодавством, сприяє захисту авторитету професійної публічної служби.

Зроблено висновок, що найважливіше значення у питанні юридичної відповідальності публічних службовців займає саме службово-трудова відповідальність, яка є теоретичним юридичним конструктом, заснованим на аргументованій в українській доктрині трудового права теорії трудоправової відповідальності, що змістовно охоплює матеріальну та дисциплінарну відповідальність працівника. На відміну від загальної теорії трудоправової відповідальності, окреслена автором теорія службово-трудової відповідальності поширюється лише на професійних публічних службовців і нормативно грунтується не лише на нормах законодавства про працю, а й на трудоправових нормах адміністративного законодавства, яке врегульовує діяльність зазначених суб'єктів трудового права.

Ключові слова: державний службовець, правовий статус, професійний публічний службовець, реформа законодавства, службовець органу публічного самоврядування, службово-трудова відповідальність, трудове право, юридична відповідальність.

В статье совершено попытку комплексно определить юридическую сущность феномена служебно-трудовой ответственности профессиональных публичных служащих в Украине на основе концепции трудоправовой ответственности. Автор анализирует имеющиеся научные подходы украинских ученых к пониманию сущности юридической ответственности в трудовом праве Украины и выделяет подход к пониманию этой ответственности, в пределах которого возможно наиболее полно сформулировать юридический конструкт "служебно-трудовой ответственности профессиональных публичных служащих».
В качестве такого подхода используется консолидирующий (гармонический) подход $к$ пониманию юридической ответственности в трудовом праве, который был сформулирован в украинской теории трудового права. Значительное внимание уделяется исследованию особенностей проявления дисциплинарной и материальной ответственности в пределах служебно-трудовой ответственности профессиональных публичных служащих. Определено, что юридическая ответственность публичного служащего характеризуется определенными присущими только ей особенностями, разновидностями и расширенными основаниями для ее наступления. Применение к публичному служащему определенного вида юридической ответственности предполагает не только осуждение поведения публичного служащего путем применения к нему публичного принуждения, но и стимулирует других лиц к должному поведению и надлежащему выполнению своих должностных обязанностей, недопущению совершения действий, которые прямо запрещены действующим законодательством, способствует защите авторитета профессиональной публичной службы.

Сделан вывод, что наиболее важное значение в вопросе юридической ответственности публичных служащих занимает именно служебно-трудовая ответственность, которая является теоретическим юридическим конструктом, основанным на аргументированной в украинской доктрине трудового права теории трудоправовой ответственности, содержательно охватывает материальную и дисциплинарную ответственность работника. $B$ отличие от общей теории трудоправовой ответственности, очерченная автором теория служебно-трудовой ответственности распространяется только на профессиональных публичных служащих и нормативно основывается не только на нормах законодательства о труде, но и на трудоправовіх нормах административного законодательства, регулирует деятельность указанных субъектов трудового права.

Ключевые слова: государственный служащий, правовой статус, профессиональный публичный служащий, реформа законодательства, служащий органа публичного самоуправления, служебно-трудовая ответственность, трудовое право, юридическая ответственность.

The article attempts to delineate comprehensively the legal nature of the phenomenon of service and labor liability of professional public servants in Ukraine on the basis of the labor legal liability concept. The author analyzes the existing scientific approaches of Ukrainian scientists to understanding the essence of legal liability in the labor law of Ukraine and highlights the approach to realizing this liability, within the framework of which it is possible to most fully formulate the legal construct "service and labor liability of professional public servants". A consolidating (harmonic) approach to understanding legal liability in labor law is used, which was formulated by Ukrainian Lawyer V.V. Hladky within the framework of his theory of labor legal liability, would provide such an approach.

Considerable attention is paid to the study of patterns of disciplinary and material liability within the service and labor lia- 
bility of professional public servants. It has been determined that the legal responsibility of a public servant is characterized by certain peculiarities, varieties and extended grounds for its occurrence. Applying to a public servant a certain type of legal responsibility implies not only condemnation of a public servant's behavior by applying to him public coercion, but also encourages other persons to behave properly and properly perform their official duties, preventing actions that are directly prohibited by the current legislation, promotes the protection of the authority of a professional public service.

It is concluded that the most important value in the issue of legal liability of public servants is occupational and labor responsibility, which is a theoretical legal framework based on the theory of labor liability in Ukrainian labor law, which substantially covers material and disciplinary responsibility. At the same time, unlike the general theory of labor liability, the theory of job liability outlined by us applies only to professional public servants and is normatively based not only on the norms of labor law, but also on the labor norms of the administrative legislation that regulates the activity of these of labor law.

Key words: labour law, legal status, legal liability, civil servants, local government officials, professional public servant, reform of legislation, service and labor liability.

Постановка проблеми та її актуальність. Юридична відповідальність $€$ одним із елементів правового статусу публічного службовця, а тому модернізація публічної служби в Україні не можлива без перегляду законодавчого та нормативно-правового закріплення цього виду соціальної відповідальності. Першочергово це стосується дисциплінарної та матеріальної відповідальності професійних публічних службовців, соціально-правове значення якої важко недооцінити. Зокрема, український науковець В.С. Венедиктов констатує, що у період широкої демократизації суспільства трудова юридична відповідальність «покликана цілковито виконати свою роль по забезпеченню безперешкодної реалізації суб'єктивних прав і належного виконання юридичних обов'язків у процесі праці, з виховання в найширшому розумінні, особистості і її поваги до права» [1, с. 210].

Окрім того, зазначене питання актуалізується й з огляду на той факт, що натепер досить часто із засобів масової інформації ми отримуємо інформацію про факти порушення публічними службовцями присяги, вчинення ними корупційних правопорушень, злочинів, здійснення інших дій, які дискредитують публічного службовця чи орган публічної служби, в якому він працює. 3 огляду на кількість таких правопорушень можна впевнено констатувати факт неналежного законодавчого та нормативно-правового закріплення юридичної відповідальності в Україні та відсутності належного і ефективного механізму реалізації відповідальності публічного службовця на практиці.

Також слід констатувати, що попри значимість інституту юридичної відповідальності та юридичної службово-трудової відповідальності професійних публічних службовців відповідні категорії ще залишаються недостатньо дослідженими українськими та зарубіжними юристами-трудовиками. Серед іншого це обумовлює той факт, що особливо складний вияв юридична відповідальність отримує саме у межах трудового права, в якій ця відповідальність вже досліджується тривалий період часу українськими юристами-трудовиками, однак поза контекстом службово-трудової діяльності.

Аналіз останніх досліджень і публікацій. Окремі аспекти юридичної відповідальності (зокрема, дисци- плінарної та/або матеріальної) держслужбовців та/або службовців органів місцевого самоврядування, працівників загалом вже досліджували українські юристи-трудовики, зокрема А.В. АндрєєВ, В.С. Венедиктов, В.В. Волинець, Д.С. Галицька, В.В. Гладкий, Л.І. Горбунова, М.І. Зубрицький, М.І. Іншин, А.Ю. Коротких, П.С. Луцюк, В.Я. Мацюк, М.В. Панченко, В.В. Пузанова, О.М. Ярошенко та інші науковці.

Проте у процесі реформування системи публічної влади в Україні та модернізації адміністративно-правого статусу публічних службовців особливо актуальними залишаються подальші пошуки шляхів удосконалення чинного законодавства у сфері юридичної відповідальності публічних службовців, перегляду ролі та значення різних видів відповідальності, внесення пропозицій щодо удосконалення процедури притягнення публічних службовців до дисциплінарної та матеріальної відповідальності.

Метою цієї наукової статті $\epsilon$ спроба окреслити юридичну сутність феномена службово-трудової відповідальності професійних публічних службовців на основі концепції трудоправової відповідальності.

Ця мета досягатиметься у результаті виконання таких завдань: 1) проаналізувати наукові підходи українських вчених до розуміння сутності юридичної відповідальності в трудовому праві України; 2) виокремити підхід до розуміння юридичної відповідальності в трудовому праві, у межах якого можна найбільш повно сформулювати юридичний конструкт «службово-трудової відповідальності професійних публічних службовців»; 3) дослідити особливості вияву дисциплінарної та матеріальної відповідальності у межах службово-трудової відповідальності професійних публічних службовців; 4) узагальнити результати дослідження.

Виклад основного матеріалу. 3'ясовуючи юридичну сутність службово-трудової відповідальності професійних публічних службовців, автор зазначає, що вона $\epsilon$ похідною від юридичного конструкту трудової відповідальності. Цей конструкт у вигляді «відповідальності у трудовому праві» вже окреслювали Д.С. Галицька [2, с. 181] та П.С. Луцюк [3, с. 102-103]. У свою чергу українська вчена В.В. Пузанова, приймаючи до уваги особливості вияву юридичної відповідальності в трудовому праві, дійшла висновку про існування «режиму трудоправової відповідальності» - «спеціального режиму у трудовому праві (субрежиму)» [4, с. 151-152].

Досліджуючи юридичну відповідальність у трудовому праві нашої держави (як базис конструкту «службово-трудова відповідальність професійних публічних службовців»), слід мати на увазі, що в сучасній доктрині трудового права, як справедливо наголошує науковець В.В. Волинець, «сформувалося три основні підходи до розуміння сутності та змісту юридичної відповідальності», а саме: 1) сепаруючий підхід, який «виражається у виділенні одного з двох видів юридичної відповідальності, який застосовується в трудових правовідносинах за законодавством про працю (тобто, дисциплінарної чи матеріальної відповідальності) в якості такого, що $\epsilon$ юридичною відповідальністю в трудовому праві» (цей підхід, на думку вченого, $\epsilon$ «повністю деструктивним», адже «вказує на потребу врегулювання матеріальної відповідальності в межах цивільного законодавства та ототожнює відповідальність у трудовому праві лише із від- 
повідальністю працівника»); 2) двохаспектний підхід, у межах якого юридична відповідальність у трудовому праві $\epsilon$ «умовно єдиною категорією, яка характеризує два окремі види юридичної відповідальності - дисциплінарну та матеріальну відповідальності» (цей підхід виник у радянській теорії трудового права й відображений у чинному законодавстві про працю); 3) консолідуючий підхід, “скорегований гармонійним підходом, інтерпретує юридичну відповідальність у трудовому праві як таку, що у подальшому має розглядатися в якості єдиної галузевої відповідальності», а тому $є$ найбільш прогресивним на сьогоднішній день [5, с. 39-41].

Необхідно зазначити, що консолідуючий (гармонійний) підхід до розуміння юридичної відповідальності в трудовому праві, якого дотримується і автор, сформулював В.В. Гладкий, зазначаючи: «У процесі реконцептуалізації юридичної відповідальності в трудовому праві як сукупності матеріальної та дисциплінарної відповідальності правове регулювання цієї відповідальності має бути зведено до регулювання цілісної галузевої відповідальності - трудоправової відповідальності, якій, слід зауважити, сьогодні присвячено безліч наукових досліджень», що $є$ досить дискусійними, недостатніми та нежиттєздатними.

Науковець наголошує на тому, що «трудоправова відповідальність увібрала в себе правову природу дисциплінарної та матеріальної відповідальності й остаточно концептуально трансформувалася у відповідну галузеву відповідальність. Те, що в науці тривалий час називали дисциплінарною відповідальністю, так само як і матеріальною відповідальністю, - завжди було в сукупності трудоправовою відповідальністю з урахуванням того, що те, що ми називали матеріальною відповідальністю, завжди було наслідком порушення суб'єктом трудового права умов трудового договору, яким було завдано іншому суб'єкту трудового права матеріальної та/або моральної шкоди. Відповідно поділ трудоправової відповідальності нежиттєздатний, навіть якщо такий поділ відбувається в умовній формі».

Недоцільність відповідного поділу науковець порівнює з поділом за цією ж логікою кримінальної або адміністративної відповідальності на відповідні вияви в них матеріальної і дисциплінарної відповідальності [6, с. 88-89]. Погоджуючись із цією позицією, автор зазначає, що відповідний підхід може бути цілком ефективно використаний також і в процесі модернізації правового статусу публічного службовця у межах триваючої реформи законодавства про публічну службу в Україні.

У цій розвідці слід вести мову про службово-трудову відповідальність публічних службовців в Україні, яка має такі вияви:

1) дисциплінарна відповідальність професійного публічного службовця, яка у загальному сенсі застосовується за вчинення публічним службовцем дисциплінарного проступку чи порушення норм етичної поведінки. За своєю суттю дисциплінарна відповідальність у трудовому праві покликана: а) сприяти збалансуванню інтересів роботодавця та працівника з питань праці; б) стимулювати належну поведінку працівників із питань праці; в) забезпечувати належний, адекватний вплив роботодавця на працівника як наслідок вчинення ним дисциплінарного проступку; г) забезпечувати понесення працівником санкцій у вигляді дис- циплінарних стягнень відповідно до характеру вчиненого проступку [7, с. 1-2].

Дисциплінарна відповідальність, яка застосовується нормативно, тісно пов'язана з дисципліною та спрямована на підвищення неналежного рівня дисципліни працівників. Встановлення належної дисципліни в органі публічної служби $є$ запорукою нормального його функціонування, своєчасним, повним i неупередженим виконанням соціальних, економічних та інших напрямів діяльності держави. Дотримання дисципліни на робочому місці створює сприятливий мікроклімат у трудовому колективі, створює умови для нормального функціонування публічного органу загалом.

У науковій і навчальній юридичній літературі поняття дисциплінарної відповідальності розглядають як покарання особи за невиконання чи неналежне виконання працівником (публічним службовцем) своїх трудових обов'язків, що $€$ дисциплінарним проступком. У контексті службово-трудової відповідальності це $\epsilon$ також порушенням працівником правил етичної поведінки, що охоплюється поняттям «дисциплінарний проступок» [8, с. 31], визначення якого міститься у ч. 1 ст. 65 Закону України «Про державну службу».

Беручи до уваги сутність цього вияву службово-трудової відповідальності, доцільно викласти поняття «дисциплінарного проступку» в означеній нормі Закону в якості винного порушення державним службовцем норм, регламентованих посадовими інструкціями, правилами внутрішнього трудового розпорядку, статуту, правилами етичної поведінки тощо чи вчинення іншого порушення службової дисципліни, які спричинили невиконання або неналежне виконання посадових обов'язків, визначених цим Законом та іншими нормативно-правовими актами у сфері державної служби та за які уповноважена особа має право притягнути винну особу до відповідальності.

Нормативно-правовим підґрунтям для застосування дисциплінарної відповідальності публічного службовця $\epsilon$ порушення посадової інструкції, типових правил внутрішнього трудового розпорядку, статутів і спеціальних положень про дисципліну працівників окремих галузей управління та окремих видів публічних службовців (посадові особи поліції, СБ України, прокуратури, судів, Збройних сил України тощо). Якщо дисциплінарна відповідальність держслужбовців на загальному рівні врегульована главою 1 «Службова дисципліна» та главою 2 «Засади дисциплінарної відповідальності» й уточняється у «статутних» законодавчих актах (законах України про СБ України, про Нацполіцію, про прокуратуру тощо), дисциплінарних статутах, то дисциплінарна відповідальність службовців органів місцевого самоврядування ґрунтується на нормах КЗпП.

Досліджуючи проблеми дисциплінарної відповідальності публічних службовців у контексті модернізації правового статусу публічних службовців та європеїзації системи суб'єктів публічної адміністрації, варто наголосити, що цей вияв службово-трудової відповідальності потребує суттєвого удосконалення. У розв'язані цих проблем можуть бути використані теоретичні напрацювання багатьох українських науковців, які досліджували можливості європеїзації дисциплінарної відповідальності публічних службовців. Це дослідження О.О. Губанова, М.І. Зубрицького, А.Ю. Коротких та інших вітчизняних науковців; 
2) матеріальна відповідальність професійного публічного службовця, яка у загальних рисах врегульована на рівні КЗпП України, норми якої у відповідній частині поширюються на публічних службовців у частині, яка не врегульована на рівні спеціальних законів. Особливості змісту матеріальної відповідальності професійного публічного службовця виражаються в: а) «специфіці інших елементів правового статусу цих службовців як суб'єктів трудового права (зокрема їх трудової правоздатності)»; б) «особливостях трудових правовідносин, які мають місце між держслужбовцем i його наймачем (розкриваються у специфіці покриття завданої службовцем шкоди, яка залежить від суб'єкта, якому була заподіяна така шкода, а саме групі людей, враховуючи і громадські об'єднання, людину та громадянина, юридичних осіб, тобто всіх третіх осіб, шкода яким, завдана працівником, покривається державою, яка в подальшому може стягнути з винного державного службовця відповідні грошові кошти в порядку регресу державі)» [9, с. 287].

Нормативним чином ця відповідальність врегульовується на рівні спеціальних законів про публічну службу, однак відповідні норми не містять порядку притягнення до цієї відповідальності службовців, які завдали шкоди, що стала фактичною підставою для притягнення їх до матеріальної відповідальності. Зокрема, у ст. 24 Закону України «Про службу в органах місцевого самоврядування» передбачається, що «матеріальна шкода, завдана територіальній громаді незаконними рішеннями сільських, селищних, міських голів, голів районних у місті, районних та обласних рад, їх заступників, керівників управлінь, відділів, інших структурних підрозділів виконавчих органів місцевого самоврядування, діями чи бездіяльністю посадових осіб місцевого самоврядування при здійсненні ними своїх повноважень, відшкодовується за рахунок місцевого бюджету в порядку, встановленому законом».

«Сільські, селищні, міські, районні у місті, районні та обласні ради, сільський, селищний, міський голова, голова районної у місті, районної та обласної ради мають право зворотної вимоги (регресу) до посадової особи місцевого самоврядування, яка заподіяла шкоду територіальній громаді, у розмірах і порядку, визначених законами України та статутами територіальних громад, прийнятими відповідно до законів України». У свою чергу в статтях 80 і 81 Закону України «Про державну службу» матеріальна та моральна шкода, заподіяна фізичним та юридичним особам незаконними рішеннями, діями чи бездіяльністю держслужбовців під час здійснення ними своїх повноважень, відшкодовується за раху- нок держави, яка (в особі суб'єкта призначення) має право зворотної вимоги (регресу) у розмірі та порядку, визначених законом, до держслужбовця, який заподіяв шкоду (матеріальна відповідальність виникає тільки за шкоду, умисно заподіяну його протиправними діями або бездіяльністю); посадової особи, винної у незаконному звільненні, відстороненні або переведенні держслужбовця чи іншого працівника на іншу посаду, щодо відшкодування матеріальної та моральної шкоди, заподіяної державному органу у зв'язку з оплатою часу вимушеного прогулу або часу виконання нижчеоплачуваної роботи. При цьому держслужбовець зобов'язаний відшкодувати державі шкоду, заподіяну внаслідок неналежного виконання ним посадових обов'язків.

Висновки. Юридична відповідальність публічного службовця характеризується певними притаманними тільки їй особливостями, різновидами та розширеними підставами для їі настання. Застосування до публічного службовця певного виду юридичної відповідальності передбачає не тільки осуд поведінки публічного службовця шляхом застосування до нього публічного примусу, а й стимулює інших осіб до належної поведінки та виконання своїх посадових обов'язків, недопущення вчинення дій, прямо заборонених чинним законодавством, сприяє захисту авторитету професійної публічної служби. В таких випадках юридична відповідальність $€$ певним виховним засобом, який здійснюється як на самого порушника, так і на інших осіб, а також $\epsilon$ бар'єром для неналежного використання службових повноважень, результатом чого може стати блокування нормальної діяльності органу публічної служби та держави загалом.

Найважливіше значення у питанні юридичної відповідальності публічних службовців займає саме службово-трудова відповідальність, яка $\epsilon$ теоретичним юридичним конструктом, заснованим на аргументованій в українській доктрині трудового права теорії трудоправової відповідальності, яка змістовно охоплює матеріальну та дисциплінарну відповідальність працівника. На відміну від загальної теорії трудоправової відповідальності, окреслена автором теорія службово-трудової відповідальності поширюється лише на професійних публічних службовців і нормативно ґрунтується не лише на нормах законодавства про працю, але й на трудоправових нормах адміністративного законодавства, що врегульовує діяльність зазначених суб'єктів трудового права (окрім службовців органів місцевого самоврядування, дисциплінарний вияв службово-трудової відповідальності яких врегульований нормами законодавства про працю). 


\section{Проблеми трудового права та права соціального забезпечення}

\section{Література}

1. Венедиктов В.С. Інститут трудової юридичної відповідальності в системі трудового права України. Вісник Харківського національного університету внутрішніх справ. 2002. № 17. С. 209-214.

2. Галицька Д.С. Адаптація національного трудового законодавства про відповідальність до законодавства Європейського Союзу : дис. ... канд. юрид. наук: 12.00.05. Київ, 2017. 206 с.

3. Луцюк П.С. Концептуальні засади юридичної відповідальності в сучасних умовах розвитку трудового законодавства: Дис. ... д-ра юрид. наук: 12.00.05. Сєверодонецьк, 2017. 468 с.

4. Пузанова В.В. Концептуалізація правового режиму трудоправової відповідальності. Проблеми юридичної науки очима молодих науковців : зб. наук. праць учасн. XII Всеукр. наук.-практ. конф. (Київ, 6 грудня 2018 року). Київ : НУБіП, 2018. С. 150-152.

5. Волинець В.В. Основні підходи до розуміння юридичної відповідальності у сучасному трудовому пра- ві. Науковий вісник публічного та приватного права. 2017. Вип. 6, Т. 3. С. 37-42.

6. Гладкий В.В. К вопросу о теории трудоправовой ответственности. Стратегічні пріоритети в XXI cm. : матеріали II Міжнар. наук.-практ. конф. (Київ, 14-15 лютого 2017 року). Київ : О.В. Пшонківський, 2017. С. 86-90.

7. Костюк В.Л. Стадії застосування дисциплінарної відповідальності: теоретико-правовий аспект. Часопис Національного університету «Острозька академія». Серія: Право. 2016. № 1(13). С. 1-14.

8. Тиха А.П. Деякі питання дисциплінарної відповідальності працівників. Юридична Україна. 2015. № 3. С. 27-32.

9. Коротких А.Ю. Проблеми юридичної відповідальності державних службовців за трудовим законодавством України : дис. ... д-ра юрид. наук: 12.00.05. Київ, 2019. 472 с.

Любимов О. К., кандидат юридичних наук, помічник судаi Вищого господарського суду України 